\title{
Noun Valences, Noun Head and its Satellites
}

\author{
Migena Kapllani \\ University "Aleksander Xhuvani" Elbasan \\ E-mail:mgnkapllani@yahoo.com
}

\section{Doi:10.5901/ajis.2012.v2n4p133}

\begin{abstract}
:
Our work consists on the valence of noun. We will of course remain on Tesnier's theory of valence, on the form it has nowadays, after uninterrupted developments. For our analysis it is essential the difference between the levels of valences. We will operate with different concepts, such as: semantic valence and syntactic valence. That's a known phenomenon and described through the grammar of valence. On each occasion it will be operated even with other levels of valence phenomenon, as for example: logic level, pragmatic level, semantic role levels. The existence of nominal valence, especially the valence of certain nominal classes, in terms of opening new places, is now admitted by different authors in the syntax field. It is also admitted that syntactic realization of arguments (complements) is different for nouns and verbs. So, you can't use in the same form the complements of verbs at the relevant verbal nouns: help her, or help for her.In my general opinion it is known that only nouns deriving from verbs which save in their semantic as a component the idea of verbal process have valences. Similarly, some nous deriving from adjectives have valences. However, not all the nouns derived from verbs or adjectives have valences. Our work will deal with a group of nouns which, even though not verbal or adjectival, have valence. Such are: road (road to Rome), nouns that indicate kinship connection, nouns that indicate human body parts etc. Our paper will describe issues such as:- Noun valence types; · the connection between semantic roles in verbs and verbal nouns;'· Syntax-formal realisation of semantic roles of verbal noun
\end{abstract}

Key words: Nouns, noun valences, valence types, syntax.

\section{Introduction}

The target of our work is the noun valence. In our work we will be based on the valence theory of Tesnier, in the form that it has today, after uninterrupted developments. The subjugation grammar considers the phrase as a collection of elements among which there are relations ( L. Tesnièr (1959:11). (In linguistics, verb valence or valence refers to the number of arguments controlled by a verbal predicate. It is related, though not identically, to verb transitivity, which considers only the object arguments of the verbal predicate. Verb valence, on the other hand, contains all arguments, including the subject of the verb. The linguistic meaning of valence derives from the definition of valence in chemistry. This scientific metaphor is due to Lucien Tesnière, who developed verb valence into a major component of his (what would later become known as) subjugation grammar theory of syntax and grammar. The notion of valence first appeared as a comprehensive concept in Tesnière's posthumously published book (1959) Éléments de syntaxe structural (Elements of structural syntax).

Tesnière's model is based on the stemma, a graphical representation of the grammatical subjugations among the words in a syntactic construction. In the sentence, the verb is seen as the highest level word, leading a set of complements, which lead their own complements themselves. Unlike the logical notion of the division of the sentence into a subject and predicate, the grammatical subject in Tesnière's work is also considered subordinate to the verb (being, nevertheless, its prime actant), a notion which finds its echo in the VP-internal subject hypothesis in transformational syntax. Moreover, in the first chapter of Éléments de syntaxe structurale,(1959) Tesnière adheres to Humboldt's notion of an 'innere Sprachform' which is not materially visible, making him a potential precursor to the opposition of "deep structure" and "surface 
structure" in generative grammar. While the notion of IP as the fundamental node of an utterance is foreign to Tesnière, his stemmata do remind one of the graphical representation in transformational syntax.

\section{The development of valence theory}

Valence theory originated in the work of the French structuralist Lucien Tesnière, in whose theory of dependency grammar valence plays a considerable role. However, the main impetus for the development of valence theory as such didn't come so much from work within dependency grammar as from foreign language teaching. The publication, in 1968, of the first valence dictionary of German verbs, theWörterbuch zur Valenz und Distribution deutscher Verben, by the two East German linguists Helbig and Schenkel marks an important step in the development of the theory. Numerous theoretical publications, especially those by Helbig (1971 and 1992) and Bondzio (1971) or Welke (1988) in East Germany, and Heringer (1970 and 1996) and Engel (1977) in West Germany, have established it as obviously the most widely used model of complementation within German linguistics and has resulted in the publication of valence dictionaries not only for German (cf. eg. Engel and Schumacher 1976).

The net known as dependency, goes round a constructive nodes,(L. Tesnière,1959: 14) that attracts a certain number of subjugated elements and imposes them conditioned roles and features. Verb is a constructive node par excellence. It leads the number and type of complements (arguments), defines at the same time the roles that complements will have in different syntactic constructions. The starting point of the valence theory is the necessity of accompaning the verb with other complementary elements (Ergänzungen). Each verb has to be followed by a précised number of elements defined to construct a meaningful phrase. The verb valences define the structure of the sentence, which means the type and number of the complementary members. Due to this the verb is given a special role in the sentence. The verb opens spaces that are to be filled with other elements in a sentence. It is the main constructive power in a sentence which creates and organizes it.

The language reality, the researches related to the valence theory, have shown that bearers of the valences, apart from verbs are other parts of speech such as noun, adjective, adverbial modifiers, some pronouns etc. In this work we will deal with the noun valences. For the analysis it is very important distinguishing different levels of valences. We will operate with concepts such as: semantic valences and syntactic valences. Occasionally we will operate with other levels of the phenomenom "valence" such as: logical level, pragmatic level, semantic roles levels.

In the semantic level the meanings of the words play a special role and define the construction of the syntactic structure. The complex description of the language requires that the semantic aspects be completed with the logical-mental one. In the logical aspect the valence sets the feature of one meaning (sememe) to open free space due to its conceptual content. The free spaces are filled up with complements. (Bondzio, W, 1969, p. 234-235)

In the pragmatic level the valence is considered in connection with the communication, the communicative situation, with the socio-cultural information. In special communicative situations what happens is that the complements even when they are optional, can not be absent in the surface syntactic structures.

The description of the language based on the theory of the valences focuses on specific concepts. Here the sentence is compared to a stage, on which it is acted a play (the content of the sentence). The verb plays the role of the director and defines the quantity and the type of the other members.

By declaring a member as the main one, the classifying schemes with two main members and three secondary members falls down.

According to the valences the members of the sentence are satellite of the central verb. They may be complements or adverbials. (Most theories of syntax and semantics acknowledge arguments and adjuncts, although the terminology varies, and the distinction certainly exists in all languages. In syntax, the terms argument and complement overlap in meaning and use to a large extent. Dependency grammars sometimes 
call arguments actants, following Tesnière (1959)). Related to the meaning and the labelling of the terms complement and adverbial I have referred to the theory of the valences, on the Engelian model. The notion of the term complement in me is the same as the one represented by Erganzung in the grammars and dictionaries of Engel (2009, p. 134). The term complement has something in common with the term used by our linguist M.Domi. (1955) In our case the traditional is reconsidered. From Tesneir up to now, among the notions mentioned are used terms such as: Aktant, Erganzung, Komplement, Mitspieler, Partizipant, Satellit or even others. The term Komplement, (Theory of X-Bar) in the dictionary of the linguistic terms, in German it is translated as Erganzung ( Bußmann, H., 2002, p.357) By using the term complement it has brought an equivalent of the term complement. The understated theory, from the categorical notional meaning can be defined with such a term.

The other term, adverbial, is not an equivalent, but responsible of the term Angabe (German). Whereas, with the term of L.Teisner cirkonstant, it has equivalent relations. The term adverbial is taken from the Grammar of the Academy (2002). Its content and volume of this concept differs from that of the Grammar of the Academy.

In the class of compliments according to the new conception, are included members of the traditional grammar such as, subject, direct object, indirect object, free dative, some adverbials, predicative complement.

In this way a sentence is made of a verb (predicate) accompanied by its subjugated members: complements and adverbials.

In our treatment the valence is a phenomenom linked with three levels: syntactic level, semantic level, and pragmatic level. With the term syntactic valence it is meant the ability and quality of the words to combine with other words and appear in the sentence in précised forms. The syntactic valence precises in what morpho-syntactic ways the complements will be gained and what superficial members they will express (subject, object, adverbial complement etc.)

The existence of the noun valences, especially the valences of certain nominal classes, in the meaning of opening free spaces, today is accepted by different authors in the field of syntax. It is also accepted that syntactic and formal arrangement of the arguments (complements) is different between nouns and verbs. In this way the verb complements can not be used in the same way with the verbal nouns: help him, but, the help for him (ndihmoj atë, por ndihma për të).

The syntactic functions and their semantic roles are different in verbs and nouns coming form them. Although the semantic roles remain the same their syntactic and formal arrangement differs. In the syntacticformal level, nouns differ from verbs, because they can not create relations without prepositions. There are few exceptions: Berisha government (qeveria Berisha) etc.

The fact that even nouns need to be accompanied by complements is relatively indisputable. In the case of nouns it is more difficult to precise the complements structure quite differently from the verb cases. (2004)

Even nouns can require obligatory complements. Here are some examples:

- Shmangia e alkolit për të ishte e nevojshme. Avoiding alcohol was something necessary for her/him.

- Nëpërmjet marrjes në konsideratë të fakteve ai pati sukses. Taking into consideration facts he was

- Në klasë hyri një djalë me dorë të lidhur.

A boy with strung hand entered the class.

- Detyra e çdo prindi është edukimi i fëmijëve. The duty of each parent is the children's upbringing.

- Ai u ngrit në majë të gishtave He stood up on the top of the toes.

- Erdhi një djalë me kokë të qethur A cropped hair boy came.

*Shmangia ishte për të e nevojshme.

* Nëpërmjet marrjes, ai pati sukses.

*Në klasë hyri një djalë me dorë .

* Detyra është edukimi.

*Ai u ngrit në majë.
The avoindance was for her/him necessary.

Through getting he qas successful.

A boy entered the class with his hand.

The duty is upbringing.

He stood on the top. 
We could have brought other examples in which the arguments related to nouns are necessary and their arrangement is obligatory. However, with the nouns, mainly the arguments (complements) are optional.
Dhe bota u shemb me zhurmë të madhe.
And the earth got destroyed in a loud noise
Ish një grua e gjatë, e bardhë, me veshje qyteti. It was e tall. white, city-like dressed woman
Kosheret e bletëve ishin aty afër dhe zjenin si ujë që rrjedh. The bee hives were near there and
boiling over like the flowing water
Sytë e tij të zbrazët u ngul ën mbi hetuesin.
He stared with empty eyes at the investigator
Dhe bota u shemb me zhurmë.
And the world got destroyed noisily
Ish një grua me veshje qyteti.
It was a woman in city-like clothes
Kosheret ishin aty afër dhe zjenin si ujë që rrjedh.
The bee hives were near there and they
were boiling like the flwoing water
Sytë e tij u ngulën mbi hetuesin
He stared at the investigator

The studies on noun valences are encountered nowadays in several cases. Such as:

1. Which nouns have valences and which not?

2. Is there a difference between the semantic valence of nouns and verbs, that is, is there a sui generis valence for nouns?

3. The differences between the semantic roles of the arguments in the verb constructions and those of responsive verbial nouns?

4. Are there rules for the combination of the semantic roles with the syntactic functions in the arguments that nouns require?

5. How are the noun valences classified?

6. How are the complements and the adverbials related to such nouns distinguished?

7. Are there necessary complements for nouns?

8. What are the similiarities and differences for both noun and verb valences?

In this research we will not deal with all the issues and problems mentioned above but with some of them.

\section{Which nouns have valences?}

According to my general opinion the nouns that have valences are those that come from verbs and those which keep in their semantics the adequate idea of verb process (diskutimi i programit - the program discussion). In this way even the nouns that come from adjectives have valences (e bardha e vezës / eggwhite); të lexuarit natën/ reading at night.)

In this way for example, the abstract derived nouns which indicate actions, states and qualities, show interest for the fact that they are an opportunity of expression besides another opportunity. When a possibility is reached, the other is excluded. This way the action or state can be given either with a verb or with an abstract noun. The more verbs that express action or states a text might have, the less abstract action or state nouns might be in it. Between the verb and noun that indicate actions or states there are semantic differences but mainly stylistic ones.

Shembuj:

Mori urdhërin për përpilimin (të përpilojë) e listës së të ftuarve.

Dëshiroj të kujtoj se fill pas shtypjes së rebelimit (pasi u shtyp rebelimi)

Menjëherë pas shpalljes së përbërjes (pasi u shpall përbërja)

U përkëdhelnin ndjenjë për sundim ... 


\section{Exapmles:}

Got the order to make up the list of the guests

I want to remember that just after the rebellion crush

Immediately after the composition declaring

They cuddled the feeling of domination...

However widespread opinions in the field of valence theories, do not support completely the theory of Sandleberg, who thinks that nouns deriving from adjectives and verbs have valences. Theorists such a $\mathrm{S}$ Teubert (1979: 81-87), Helbig (1992), Welke (1988: 115-149) and Kubvaz/Schumaker (1998: 276, 283), support the idea that there are nouns which do not derive from verbs or adjectives but have valences.

However, even the nouns that derive from verbs or adjectives, don't have in all the cases valences even though they keep in their semantic structure the component known as "predication". So when nouns express action result they can appear even alone. (The lesson starts at 8). This component is the indicator of the origin from the verb and the nouns that contain it are nearly all of them verbal.

In our work we have distinguished a group of nouns, which, even though they are not from a verbal origin or adjective, have valences. Such nouns are as following:

- Nouns that show familiar relationship. Valence frames of nouns referring to blood (family) relations. Nouns referring to blood relations (and other nouns similar in meaning) are usually non-derived. Examples: (baba - father, xhaxha - uncle, vëlla - brother). Expressing the relevant relation is considered obligatory for these nouns.

- Nouns which show parts of the body (kokë - head, krah - arm, këmbë - leg )

- Nouns of intellectual products are (both derived and non-derived) nouns denoting products of scientific or artistic work (in the broad sense of the word), for example: (skulpturë - sculpture), (pikturë - painting), (roman - novel), ( monografi - monograph), (kujtime - memoirs).

- General definitions which need specifications through parts and type (një tufë viçsh / a herd of veals, një gotë birrë / a beer glass etc.)

These are distinguished from the zero valence nouns such as: dog, stone, woman, man etc.

\section{Distinguishing complements and adverbials in nouns with valences}

The most useful criteria to distinguish complements and adverbials semantically and syntactically linked with nouns are those proposed by Teubert $(1979$, p.37) and Helbig (1995, p. 72). Teubert is a precursor of the theory of the noun valences. He is a supporter of the idea that the complements related to nouns are mainly optional.

The criterion proposed and elaborated by Teubert: this is known as the criterion of the connection with specific classes. The noun complement connects only with a specific class of nouns, depending on specific nominal classes: the problem solution, the reading of the book etc. Whereas the adverbials which complete the meaning of the nouns connect with whatever noun: field, stone, village, the wolf in the mountain etc.

Helbig makes the difference among the complement and the adverbial depending on the noun valences, in a sentence level. His distinguishing criterion is that of necessity completed by the criterion of the specific class. The criterion of the depending member on a specific class of nouns Helbig explains as the impossibility of this member to appear in whatever conditions, but only on the free spaces opened by nouns e.g. : reading of the book. The noun reading opens space only for elements that can connect to it semantically.

Gianno Pannonio (2004) in his efforts to create an Italian- Hungarian dictionary of valences of the noun , has used those nouns that can take arguments. Here it is given information upon the possibility that the noun has to build nominal structures in subjugation relations. 


\section{Classification of the complements subjugated to noun valences}

In the classification of the complements category subjugated to the noun valences the opinions of the linguistics differ. This has to do with the different basis of the theory and the terminology not integrated up to now. Among the different classification theories we have distinguished those of Teubert (1979, p. 88), Engel (2004, p. 118), Eroms (2000, p.6).

Teubert in his classification uses two theoretical basis: the grammar of the structural indicators and the grammar of subjugation. He distinguishes and defines 17 complement classes related to 12 noun classes that demonstrate valences. He also distinguishes 9 classes of adverbials related to the same noun classes. The nominal complements distinguished by Teubert can be displayed as below:

Klasa e plotësit
Plotësi i veprimit
Plotësi kundrinor/objektor
Plotësi i rezultatit
Plotësi i gjendjes
Plotësi i vetisë
Plotës farefisnie
Plotësi i autorit të ngjarjes/shkil kategorial
Plotësi kation
Plotësi i llojit
Plotësi i masës
Plotës institucional
Plotës i drejtimit
Complemen class
Action complement
Object complement
Result complement
State complement
Feature complement
Family complements
Author/beginner of the event
Categorical complement
Type complement
Quantity complement
Institutional complement
Direction complement

\section{Shembuj}

(sulmi i anglezëve, referati i nxënësve, mësymja e armiqve)

(mobilimi i shtëpisë, leximi i librit, diskutimi i romanit)

(shpikja e Edisonit, teoria e Njutonit, tabela e Mendelejevit)

(zagushia e ajrit, prishja e ambjentit)

(pastërtia e xhamit, fisnikëria e mësuesit)

(babai i Piterit, vëllai i Arbenit, e bija e Mirit, kushërira e parë)

ktarit (pjesëmarrës në festim, autori i librit)

(zona e Hanoverit, qyteti i Berlinit)

(rezerva e naftës, sasia e benzinës, nxënësit e klasës)

(një kile nga kafeja më e mirë, dy kilogram misër, shtatë litra qumësht)

(regjimi i Brandt, qeveria Nano)

(rruga për në Teksas, ardhja nga Bari)......

\section{Example}

(English attack, the students' reference, the enemy's invasion) (house furnishing, reading of the book, discussion of the novel)

(Edison's invention, Njuton's theory, Mendelejeve's table)

( sultriness of the air, spoiling of the environment)

( the glass clearance, the nobility of the teacher)

(Peter's father, Arben's brother, Fatmiri's daughter)

(participants in the celebration, the author of the book)

(Hanover area, Berlin City)

(oil deposit, the quantity if the petrol, the students of the class)

(a kilo form the best coffee, two kilograms of corn, half a litter oil)

(Brand regime, the Ministry of Education, Nano government)

(way to Texas the arrival from Bari )...

Eroms (2000, p. 16) in his theory of nominal complement classification makes a combination of the subjugation grammar with the generative grammar and the pragmatics. He is indicated by the general principle that the words can be used alone or accompanied by other words. In such structures they can serve as head and keep the main meaningful power of the sentence. Eroms distinguishes five nominal complement classes:

Prepositional Attributes (Atribute parafjalore) I (prepositional complements) (plotësa parafjalorë)

Direction Attributes (Atribute drejtimi) I (direction complements) (plotësa drejtimi)

Expansive Attributes (Atribute ekspansive) I (expansive/quantity complements) (plotësa ekspansivë/mase)

Equivalent Attributes (Atribute equivalente) / ( equivalent complement) (plotësa ekuivalentë) 
Situational Attributes (Atribute situative) / (situational complements) (plotësa situativë)

\section{Examples:} dictionary

Prepositional Attributes - the discussion about the writer, thoughts about the film, translation without

Direction Attributes - the arrival from Bari, a ferry to Trieste

Expansive Attributes - the two hour prolonging of the séance

Equivalent Attributes - Artan, student of the third grade, Agimi, an engineering student

Situational Attributes - staying on the road, living in London

It is worth explaining the term Attribute used by Eroms (even by other researchers of this field) is an equivalent of the term complement. In grammar, a noun adjunct or attributive noun or noun premodifier is an optional noun that modifies another noun, meaning that it can be removed without changing the grammar of the sentence; it is a noun functioning as an adjective.In fact we have used the term complement in harmony with the international literature and the theory of the valences in which this term operates. But nominal complements are attributes, they have the attributive function. They complete the meaning by giving a determinative quality of the noun in case gender and such a function is played even by the adjective. The noun is filled with adjective complements.

It is also worth adding that the distinguished classes by the Eroms part from the function of the complement can have the function of the adverbial.

\section{Engel's theory and its application in Albanian language}

Ulrich Engel's theory (Deutsche Grammatik, München, 2004, f. 293- 304), over the nominal complement classes is going to be treated in a separate paragraph for the simple reason that it is more inclusive. On the other hand it is more comprehensive in the Albanian language context. We have tried to bring it in our language and use it in the classification of the nominal complements.

In the nomianl complements Engels includes:

subjective generative
objective genitive
pronuon genitive
explanatory genitive
prepositional attributes
origine complements
direction complement
quatity complement
verbal complement
quality complement
situational complement
copmany complement
relative clauses
apposition

Taking into consideration the restriction of such a research we will not deal with the definition, elaboration and the illustration of the distinguished classes. This will be the object of other researches.

We will be consodering a brief illustration, an exapmle for each complement.

\section{Subjective genitive Objective genitive Pronoun genitive Explanatory genitive}

the decision of Artur Agolli (Vendimi i Artur Agollit) murderer seizure (Arrestimi i vrasësit) brother's car (Makina e vëllait) the civil war problem (Problemi i luftës civile) 


Prepositional attribute
Origin complement
Direction complement
Quantity complement
Verbal complement
Quality complement
Situational complement
Company complement
Relative clauses
Apposition

\author{
the resemblance with the mother (Ngjashmëria me nënën) \\ the phone call from Vlora (Telefonata nga Vlora) \\ the way to Tirana (Rruga për në Tiranë) \\ width $8 \mathrm{~m}$ (Gjerësia $8 \mathrm{~m}$...) \\ the fear that he won't come in time (Frika se nuk do të vijë në kohë) \\ blonde boy (Një djalë me flokë bjond) \\ the bench in the garden (Stoli në kopsht) \\ a woman with umbrella (Një grua me çadër) \\ the flower that we planted yesterday (Lulja, që mbollëm vjet) \\ Agimi's house, Abuilding with five floors... (Shtëpia e Agimit, një \\ godinë me pesë kate...)
}

From the three referred researchers, Teubert and Engel have more classes than Eroms. This is because of the fact that the last researcher in a single class of attributes includes some complement classes, so we can find similarities from the meaning point of view.

\section{Conclusions}

Even the "freak" researchers of the verbal valences such as Tesnier, Engel, Eroms etc. accept that even nouns have valences, that it the ability to open free spaces around them and lead semantically and syntactically members of the sentence to fulfill these spaces.

Of course the noun valence is different from the verb valence not only from the meaning of the subjugated members as well as their morpho-syntactic arrangement.

It happens that even nouns require elements to be arranged obligatory. (a boy with cropped hair).

The members that are conditioned by the noun valences we have called as complements and adverbials in harmony with the terminology used in the verbal valence theory. As explained in our elaboration, noun complements are mainly attributes. Nominal complements are mainly optional members. In most of the cases the can not be arranged in a sentence and this last one is not grammatically spoilt.

The theories upon the noun valences have a great importance in the construction of the dictionaries. Such dictionaries, in which there are given nominal and verbal complements, are favorite, useful and productive in the native language but especially in the foreign language. The studies in the field of the valence are new in our language. The research in the field of nominal valences are so new that the there is still no well defined experience that will serve as the basis or initial point in the further researches. We mentioned this to justify our modest thoughts and research in this field.

\section{References}

Bondzio, W.: (1969). Die Stellung der Valenz im Rahmen der Satzstruktur, Berlin.

Bußmann, H.: (2002). Lexikon der Sprachwissenschaft, Stuttgart.

Deutsche Grammatik, 2004, München.

Domi, M.: (1955). „Gramatika e gjuhës shqipe“, II, Tiranë.

Engel, U.: (2009). Syntax der deutschen Gegenwartssprache, Berlin.

Eroms, HW., 2000, Syntax der deutschen Sprache, Berlin, New York.

Gramatika e Gjuhës Shqipe II; (2002). Tiranë, Kreu 13 Rrethanori.

Helbig, G., (1995). Probleme der Valenz-und Kasustheorie, Tübingen.

Pannonio,Giano,: (2004), Confronto delle reggenze nominali tra italiano e ungherese., p. 93-114 Confronto delle reggenze nominali tra italiano e ungherese. Giano Pannonio, 6-2004, 93-114.

Questa conferenza e la partecipazione dei relatori ungheresi a questo Convegno sono state realizzate nell'ambito dei finanziamenti OTKA T 037604/2002, gestiti da Zsuzsanna Fábián.

Waltraud Weindenbusch Valenz von Substantiven 
E-ISSN 2281-4612

ISSN 2281-3993
Academic Journal of Interdisciplinary Studies Published by MCSER-CEMAS-Sapienza University of Rome
Vol 2 No 4

May 2013

Tesnière, L., (1959). Éléments de syntaxe structurale, Klincksieck, Paris.

Teubert, W., (1979). Valenz des Substantivs, Düsseldorf. 
